\title{
Key Success Factors of e-Learning Implementation in Higher Education
}

\author{
https://doi.org/10.3991/ijet.v15i17.14293 \\ Tedi Priatna ${ }^{(\mathbb{})}$ \\ UIN Sunan Gunung Djati Bandung, Indonesia \\ tedi.priatna@uinsgd.ac.id \\ Dian Sa'adillah Maylawati \\ UIN Sunan Gunung Djati Bandung, Indonesia \\ Universiti Teknikal Malaysia Melaka, Malaysia \\ Hamdan Sugilar, Muhammad Ali Ramdhani \\ UIN Sunan Gunung Djati Bandung, Indonesia
}

\begin{abstract}
This study aims to analyze the Key Success Factors (KSFs) of elearning implementation so that e-learning can work well and provide maximum benefits for the learning activities process in higher education. The method used in this research begins to investigate the determinant factors based on the results of literature studies and survey techniques. To obtain a more in-depth analysis, then the factors are weighted using the Multi-Attribute Utility Theory (MAUT) method. The results showed that the determinant factors that need to be used as the primary consideration in the implementation of e-learning at higher education are organizational factors, technology, and human resources. The dominant factor that needs attention in realizing the effectiveness of the implementation of e-learning in higher education is the organizational aspect, which is recognized in the form of creating a work culture and setting policies that are binding on the academic community to carry out e-learning.
\end{abstract}

Keywords-Determinant factors; e-learning; key success factors; multiattribute utility theory.

\section{Introduction}

The development of information technology became a part of the emergence of the digital revolution era. The rapid development of information technology has given a big influence and dominates all sectors of people's lives, including in the world of education [1]. The central role of the information technology implementation in higher education is marked by the emergence of various terms of the application of technology in higher education, such as Techno University [2], Digital Campus [3,4], Smart Campus [5-8], Green Campus [9], and various other terms. These terms basically indicate that technology is applied in every activity in higher education with 
various technological approaches, ranging from information systems, artificial intelligence, and the Internet of Things (IoT), including e-learning inside.

The learning process with the face to face system is the main model in the learning process in higher education. However, in recent developments, the transformation of learning models by utilizing e-learning has been widely implemented in higher education. E-learning is the use of technology as an effective solution for the active, independent, quality, and sustainable learning process. The implementation of e-learning is seen as having excellence in shaping independence in the learning process to achieve educational goals [10]. One important thing that becomes the background of this research is the implementation of e-learning that conducted to ensure an effective and sustainable education process. Today, in Indonesia and several other countries, set lock-down policies for learning activities in several universities. This lock-down activity is carried out as anticipation to reduce the transmission of the Corona Virus Disease 2019 (COVID-19) [11-14]. E-learning is used as an alternative learning process that is considered safe from human interaction activities that can trigger the transmission of the virus; on the other hand, the learning process can continue to run well.

The related previous research has been conducted to evaluate e-learning, either using KSF or other, including:

1) Analysis of determinant factors in software design for computer-assisted instruction [15]

2) Investigating key factors for successful e-learning implementation [16]

3) Determinant factors in multimedia-based e-learning design [17]

4) Another research evaluate e-learning using Technology Acceptance Test (TAM) [18-25]

5) Critical success factors to evaluate e-learning implementation [26,27]

6) Knowledge management and e-learning effectiveness had been proven capable to improve efficiency in learning process [28]

7) Research and Development using ADDIE (Analysis Design Develop Implement Evaluate) used model to evaluate blended learning [29]

8) Actually, e-learning innovation based on research-based learning approach can improve student capabilities in learning [30]

9) Also the empirical study which evaluate using DeLone and McLeane success model, TAM, user satisfaction methods, and e-learning quality model [31]

However, different from others, this research focuses on determining, weighting, and analyzing KSFs in implementing e-learning in higher education using MultiAttribute Utility Theory (MAUT).

Based on the observations on the research object, although various supporting devices have been provided, the implementation of e-learning is not optimal, even in most lectures are not using e-learning. Moreover, in much other higher education, it was indicated that the use of e-learning was not optimal, as reported by Lestari and Hamka (2019) [32]. There are many reasons for the ineffectiveness of e-learning implementation, including the fact that lecturers are comfortable doing the learning process using only face-to-face models, policies that do not support the implementation 
of e-learning [32], user inconvenience in running the application program [33], human resource capacity, availability of supporting facilities and infrastructure [34], technological knowledge level, and work culture.

This research was conducted to analyze Key Success Factors (KSFs) to identify the determinants of the e-learning implementation. KSFs will be useful as a basis for university policy in the implementation of e-learning systems. Therefore, the implication of this study is the creation and awakening of the optimization of the e-learning implementation in higher education. The optimization considers several aspects that support the successful use of e-learning for all academic communities in higher education - both the implementation of the normal condition of academic activity and academic activities in emergencies.

\section{$2 \quad$ Methodology}

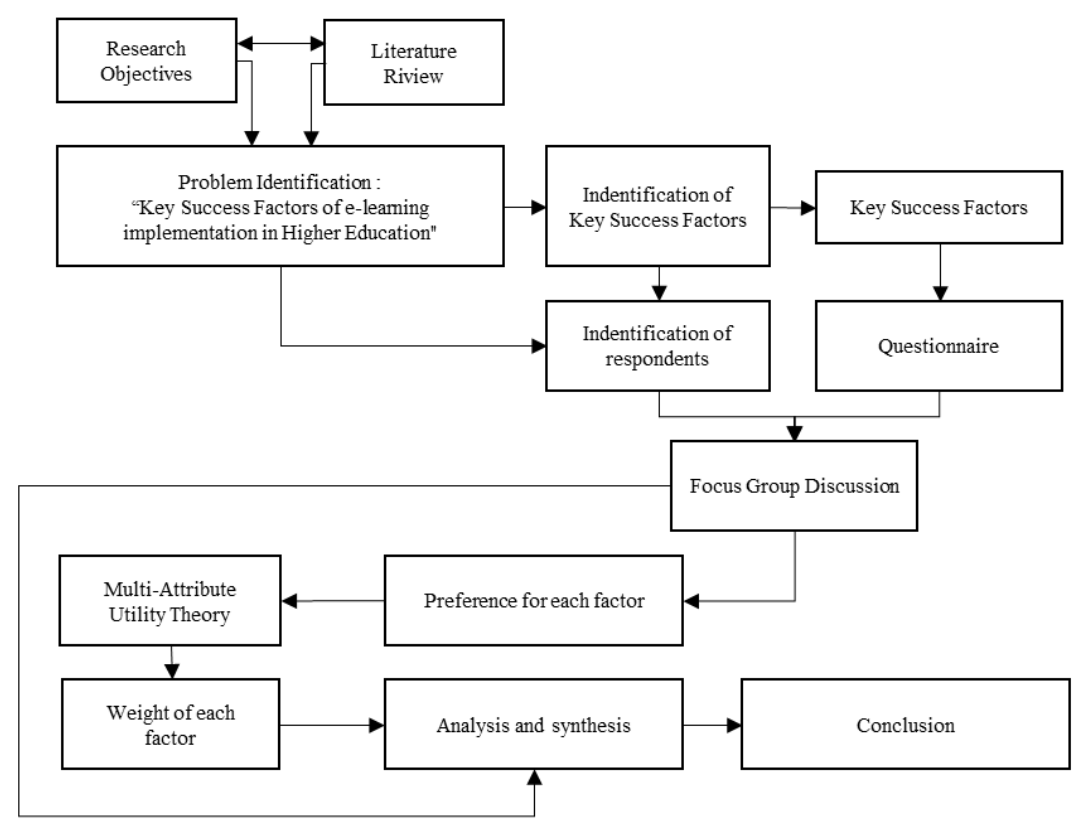

Fig. 1. Research Procedures

The research begins with a literature study, observation, and survey of the implementation of e-learning on the research object, followed by a weighting calculation with weighting that is commonly used in Multi-Attribute Utility Theory (MAUT). The assessment mechanism for each criterion is determined through the preparation of criteria followed by an assessment of each criterion using the preference scale used in the Analytical Hierarchy Process (AHP) developed by Saaty [35-37]. The research procedures or activities are presented in Figure 1. Begin from investigating the re- 
search objectives, kinds of literature, and identifying the problem. Then, KSFs will be identified and evaluate by questionnaire and Focus Group Discussion (FGD).

This study uses the AHP questionnaire model that involved by 12 experts, namely education experts, top management of higher education, and information systems experts in Universitas Islam Negeri (UIN) Sunan Gunung Djati Bandung, Indonesia. The experts who filled out the questionnaire also involved two experts from outside UIN Sunan Gunung Djati Bandung, among other experts from the High School of Garut Technology, Indonesia, and Universiti Teknikal Malaysia Melaka, Malaysia. Filling out the questionnaire is a pairwise comparison that is filled based on the AHP scale (1-9), where reference data is the consensus of respondents (expert). Data processing uses the AHP Priority Calculator (online) as provided at https://bpmsg.com/ahp/ahp-calc.php. For each factor is weighted using MAUT then the result will be analyzed and synthesized until getting the conclusion. The limitation of the study that conducted in this study about using the definition of e-learning as a learning process by combining digital technology as a service for transferring learning content [38], which is utilized and conducted focus in higher education.

\section{$3 \quad$ Result and Discussion}

Based on the results of literature review, observations, and surveys conducted on research objects, KSFs were identified as the main considerations in the success in implementing e-learning, among others:

1) Aspects of the organization (culture, and policy/ role)

2) Technology aspects (availability, reliability, accessibility, usability, and content)

3) Aspects of human resource capacity (knowledge, skills, and attitude). Figure 2 describes the relation of those KSFs aspects

Data processing of the questionnaire result shows that the use of e-Learning is in third place after the Academic Information System and the Employment Information System. This shows that the use of e-learning is quite high in the academic community of higher education, especially for Lecturers and Students as direct users of eLearning. Of course, e-learning implementation is influenced by several factors. This study uses aspects of the KSFs contained in Figure 2 to evaluate the use of e-learning in higher education. 


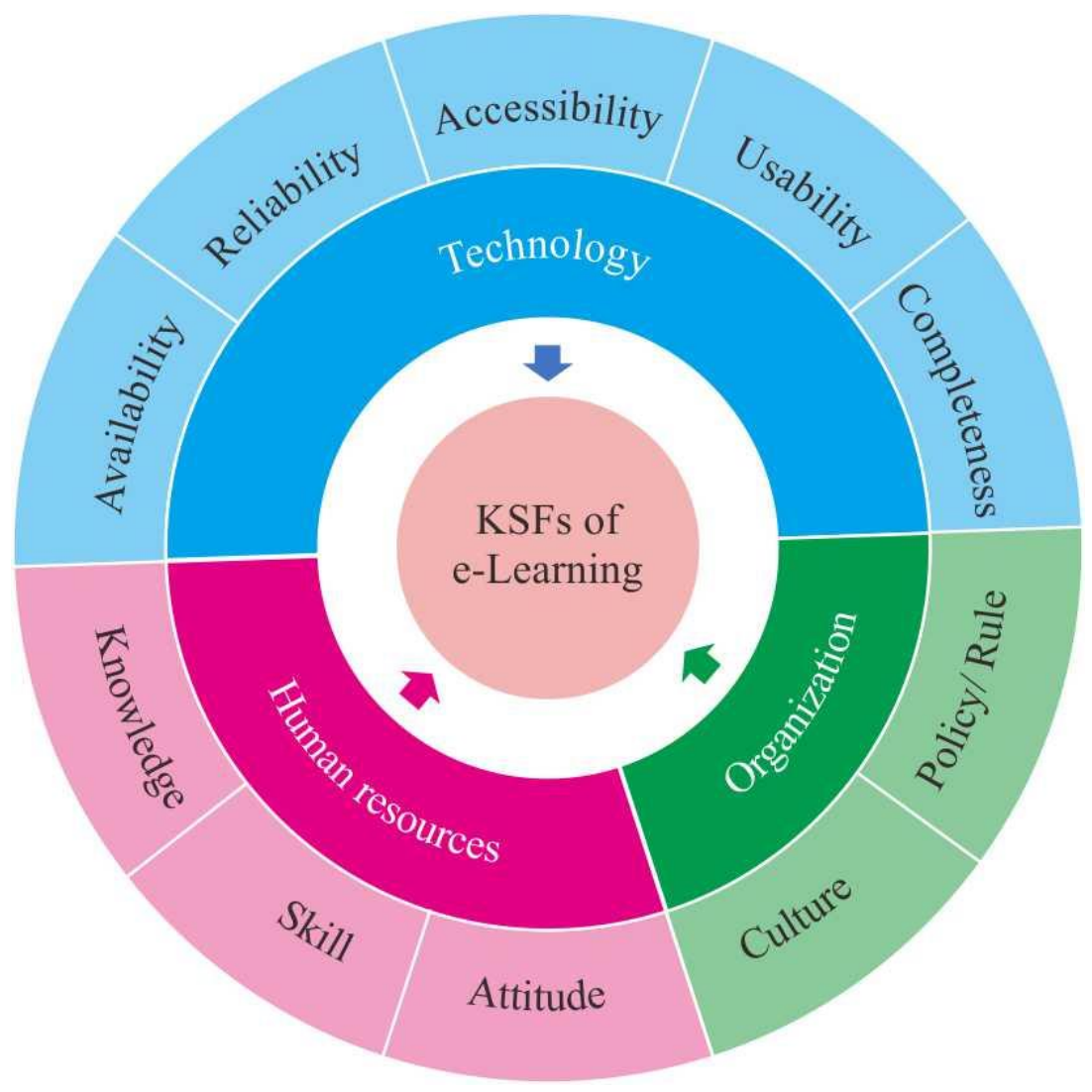

Fig. 2. Key Success Factors of e-Learning Implementation

Based on the results of the assessment conducted through the FGD, which is processed using the AHP calculation model, the weight of each factor is obtained, as presented in Table 1. In Table 1, the value in the weight column shows the importance relative to other criteria in e-learning implementation. The greater value indicates greater significance towards the implementation of e-learning. The weight value, which is calculated using AHP showed that organization has the highest value (0.5499), which means organization the most influence KSFs for e-learning implementation in higher education. Then, followed by technology (0.2402) and human resources (0.2098). Technology and human resources have a weight that is not a too significant difference. This is because the technology needs to be supported by human resources and vice versa. 
Table 1. Weighting of determinant factors in e-learning implementation

\begin{tabular}{|c|c|c|c|}
\hline Key Success Factors & Weight & Dimension & Weight \\
\hline \multirow{2}{*}{ Organization } & \multirow{2}{*}{0.550} & Culture & 0.367 \\
\hline & & Policy & 0.183 \\
\hline \multirow{5}{*}{ Technology } & \multirow{5}{*}{0.240} & Availability & 0.019 \\
\hline & & Reliability & 0.086 \\
\hline & & Accessibility & 0.061 \\
\hline & & Usability & 0.037 \\
\hline & & Completeness & 0.037 \\
\hline \multirow{3}{*}{ Human Resources } & \multirow{3}{*}{0.210} & Knowledge & 0.050 \\
\hline & & Skill & 0.029 \\
\hline & & Attitude & 0.131 \\
\hline
\end{tabular}

\subsection{Organization}

E-learning is an effort to build learning that makes it easy for students to improve their knowledge and skills-based online system. The use of e-learning depends on the user's perspective. Generally, technology will be used if the technology is a necessity, and there is a policy of the organization [39].

The needs and policies of the organization will construct an organizational commitment. Organizational commitment is the extent to which an individual knows and is bound to his organization. An individual who is highly committed will see himself as a true member of the organization [40]. Organizational commitment will be constructed through the creation of organizational culture and policies that bind the academic community.

Culture: Organizational culture is a set of values systems, beliefs, assumptions, or norms that are applicable, agreed upon, and followed by members of an organization as guidelines for behavior and solving the problems that occur in the organization [41]. In this research, organizational culture is limited to digital culture, which is a set of norms that regulate and familiarize the academic community using digital devices as part of the working system of the academic community.

Cultural weight is the highest value in ensuring the implementation of e-learning. Some research states that culture has a positive and significant effect on the implementation of e-learning [42][43]. To improve digital culture, it can be implemented through primary and secondary mechanisms [44]. In the primary mechanism, organizations diffuse culture in their members through (1) their primary concern in measuring, monitoring and setting rules; (2) how leaders react when organizations face critical and critical situations; (3) allocating resources; (4) behavior that is intentionally shown, taught and directed; (5) giving awards and positions; and (6) how to recruit, select, promote and fire members. In the secondary mechanism that is strengthening, subordinates can capture the prevailing organizational culture through: (1) organizational design and structure; (2) organizational systems and procedures; (3) organizational ceremonies; (4) spatial design, physical arrangement and institutional building; (5) a history of events and important people from the organization; and (6) official organizational slogans, philosophies, beliefs and charter of the institution. 
Both of these mechanisms show that organizational culture can be embedded in the awareness of the academic community through daily activities in tertiary institutions in completing teaching tasks that are directed for the implementation of e-learning, not just in the form of planned programs.

Policy: The policy is a series of program plans, activities, actions, decisions, attitudes, to act or not act carried out by the parties (actors), as a stage for solving the problem. Policy determination is an important factor for an organization to achieve its objectives [45].

The organizational policy basically regulates something that should and should not be done by its members. University policy is a binder for the academic community to run e-learning, which can be through punished and reward. Implementation of the use of digital devices needs to be governed by policies/regulations decided by the university as an obligation inherent in the main tasks and functions of the academic community. To maintain the effectiveness of the implementation of this policy, the university allocates sufficient resources to increase the capacity of the academic community's resources so that e-learning implementation can run effectively and efficiently.

\subsection{Technology}

Technology is applied-practical and systematic knowledge that is useful in meeting human needs [46]. Technology contains all processes that carried out in an effort to realize something rationally [47]. Consideration of technological aspects in the context of implementing e-learning based on observations and surveys are availability, reliability, accessibility, usability, and completeness of the content.

Availability: E-learning is one of the educational services that facilitate students to carry out the learning process both in the classroom and outside the classroom without the separation between space and time. E-learning is generally implemented by utilizing web-based technology [48]. The availability of e-learning facilities at higher education is an important aspect as a key factor in the success of e-learning implementation. The availability of e-learning facilities is based on the balance that through elearning can help the learning process quickly and easily. Completeness of e-learning facilities can encourage students to have the strength or ability to be able to explore or search, deepen, and expand the course material they learn through various learning resources online. On the other hand, the availability of e-learning tools facilitates the formation of a learning culture, also encourages expression in student interest to learn and to explore their own knowledge and information actively and independently.

Reliability: The reliability aspect of the e-learning application system is one of the key factors in the successful implementation of e-learning. Some parameters of the reliability of e-learning application systems include time savings, cost savings, increased effectiveness, technology development, and staff development [49].

Accessibility: E-learning is a learning process where the delivery of material, discussions, and other lecture activities is carried out through electronic media. Elearning is a learning system that allows the delivery of teaching materials to students using internet media, intranets, or other computer network media [50]. The e-learning 
functionality depends on the accessibility of the academic community to computer/internet networks.

For universities that are the object of research, network accessibility is not a major obstacle in implementing e-learning. The support of computer network infrastructure has supported the implementation of e-learning. Different things for students, the internet network accessed by students in positions outside of campus still has problems. Limited internet access is one of the obstacles to implementing e-learning for students.

Usability: The reaction and perception of the user of the technology will affect the attitude in acceptance of the technology. The aspect that can influence user acceptance for technology is whether the technology easy for use (usability) [51]. The usability aspect of e-learning is the reason for technology users to implement a technological device. The ease of use of e-learning is a considering aspect as a benchmark in the acceptance of a technology, which in turn will make the basis for the formation of the person's actions/behavior towards the implementation of e-learning as a learning medium.

There are six indicators to measure the construct of e-learning usability, namely: ease of learning system (easy of learn), ease of system to be controlled (controllable), interaction with systems that are easily understood and clear (clear and understandable), the flexibility of interaction (flexibility), easy to skilled at using the system (easy to become skilled), and easy to use [52]. The e-learning tool is designed so that it can be used as a medium for discussion with selected themes. Discussion is one of the effective education patterns in stimulating students' critical abilities [53].

Digital devices that are designed must be simple, uncomplicated, and easily run by the academic community, given the capability of digital knowledge from the academic community, which is not always high. The easier the practice of digital applications, the higher the use of e-learning by the academic community. The complexity of digital applications has a great influence on the implementation of e-learning. The aspect of ease of use of e-learning will encourage the attitude of use towards the use of e-learning.

Completeness of content: Innovative and creative learning models manage and develop learning components in a planned design. E-learning design needs to pay attention to the actual conditions of the supporting elements in the implementation of learning to be carried out. Information content on e-learning that is suitable for the learning needs of students both in terms of accuracy, relevance, completeness, timeliness, and attractive format will give satisfaction to the information received. 

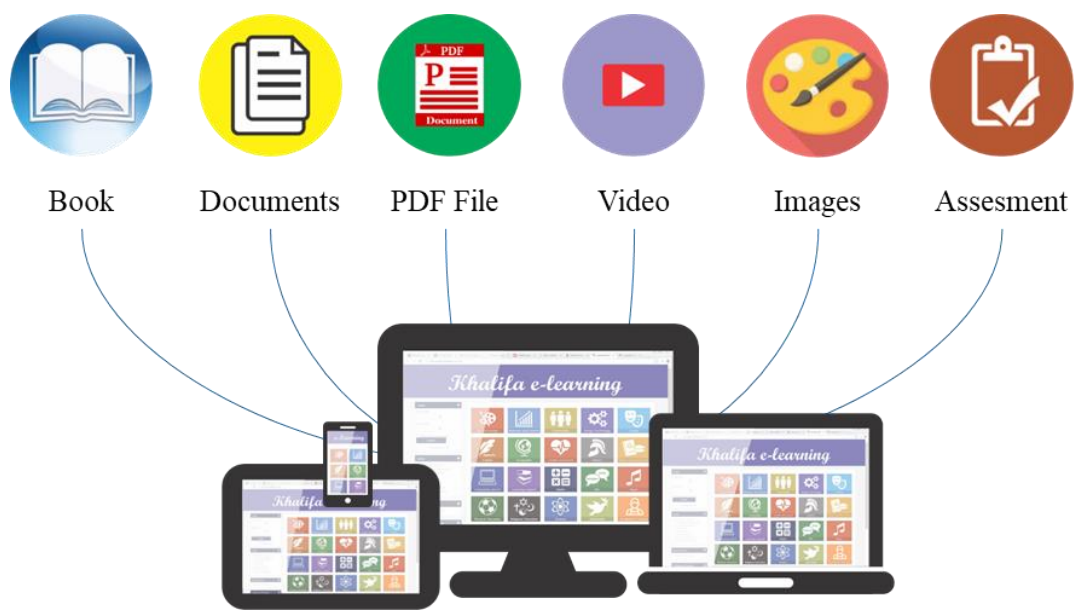

Fig. 3. Content multimedia on e-learning system[17]

Information quality and completeness can help to optimize the use of e-learning to support learning activities [54]. Digital devices that implemented at universities must be felt like a necessity by the general academic community so that the academic community is comfortable in running the application. The use of digital applications will be the needs of the academic community if the application can help the work done by the academic community. The digital application that used as content multimedia on e-learning (available in Figure 3), such as an e-book, digital documents, video, images, digital assessment, can enrich, complement, and complete the information in e-learning.

To explain a learning material well, the multimedia component of e-learning is expected to explain visually and conceptually of the learning material. The availability of learning modules in various formats can create an effective learning process [55]. E-learning is also expected to accommodate the learning evaluation process conducted by lecturers and students.

\subsection{Human Resources}

Knowledge: One of the KSFs for e-learning implementation is ownership of adequate knowledge about e-learning systems. Knowledge is a combination of framed experience, values, contextual information, expert insight and grounded intuition that provides an environment and framework for evaluating and incorporating new experiences and information [56]. Knowledge is the result of one's reflection or experience. Knowledge is attached to language, rules and procedures, and concepts [57]. The knowledge factor is an important factor in the development and implementation of information systems [58][59].

Based on observations at the research object university, it was found that the fact of the lack of knowledge of the academic community about the practice of implementing e-learning. The university's efforts include publishing a manual book on the imple- 
mentation of e-learning. As an important note, the capacity of human resources owned by the university is good, making it possible for increased knowledge to be able to understand the e-learning application system.

Skill: Skills are the ability to use reason, thoughts, ideas and creativity in doing, changing, or making things more meaningful so as to produce a value from the results of the work. Personal skills of information system users play an important role in the implementation of information systems [60]. Skills are aspects of the expertise of the academic community in carrying out e-learning that can be formed through the habituation of the use of e-learning systems in the learning process.

Attitude: Human behavior/ attitude is essentially a human activity, which has a very broad range, including walking, talking, acting, thinking, perception, and emotions. Behavior can also be interpreted as an organism's activity, both of which can be observed directly or indirectly [61]. Behavioral aspects (attitude) affect the success or failure of information systems [39]. Often the information system fails because when it is used the system is not accepted by its users. In order for an information system to be well received by its users, the rejection behavior needs to be changed and/ or the system needs to be prepared so that the recipient's behavior will accept the system. In addition, user behavior influences the ethical use of e-learning.

\section{Conclusion}

Optimization of e-learning can occur if KSFs are fulfilled in e-learning implementation. The KSFs identified for the effectiveness of e-learning include aspects of the organization (culture and policy/ role), technology (availability, reliability, accessibility, usability, and content), and human resource capacity (knowledge, skills, and attitude). Where every aspect influences one another, but the finding shows that the organization aspect is the most influenced the e-learning implementation, then followed by technology and attitude. For further works, this KSFs model can be applied and evaluate more broadly in higher educations.

\section{$5 \quad$ References}

[1] Setyaningsih R, Abdullah A, Prihantoro E, Hustinawaty H. Model penguatan literasi digital melalui pemanfaatan e-learning. J ASPIKOM 2019; 3:1200-14. https://doi.org/10.24329/aspikom.v3i6.333

[2] Jamaluddin D, Ramdhani MA, Priatna T, Darmalaksana W. Techno University to increase the quality of islamic higher education in Indonesia. Int J Civ Eng Technol 2019.

[3] Kurniadi D. Perancangan Arsitektur Sistem E-academic dengan Konsep Kampus Digital Menggunakan Unified Software Development Process (USDP). J Wawasan Ilm 2014.

[4] Mahmud ME. Mewujudkan Sekolah Atau Kampus Digital. Din Ilmu 2011.

[5] Abuarqoub A, Abusaimeh H, Hammoudeh M, Uliyan D, Abu-Hashem MA, Murad S, et al. A survey on internet of things enabled smart campus applications. ACM Int. Conf. Proceeding Ser., 2017. https://doi.org/10.1145/3102304.3109810.

[6] Dong X, Kong X, Zhang F, Chen Z, Kang J. OnCampus: a mobile platform towards a smart campus. Springerplus 2016. https://doi.org/10.1186/s40064-016-2608-4. 
[7] Veeramanickam MR., Mohanapriya M. IOT enabled Futures Smart Campus with effective E-Learning: i-Campus. Int J Eng Technol 2014. https://doi.org/10.5176/2251-3701.

[8] Alghamdi A, Shetty S. Survey toward a smart campus using the internet of things. Proc. 2016 IEEE 4th Int. Conf. Futur. Internet Things Cloud, FiCloud 2016, 2016. https://doi. org/10.1109/FiCloud.2016.41.

[9] Wang HI. Constructing the green campus within the internet of things architecture. Int J Distrib Sens Networks 2014. https://doi.org/10.1155/2014/804627.

[10] Kango R, Ghozi S. Tantangan pembelajaran E-Learning di perguruan tinggi. SemanTECH (Seminar Nas. Teknol. Sains dan Humaniora), vol. 1, Gorontalo: 2019, p. 137-44.

[11] Ansyari S, Darmawan Z. Begini Langkah UI Tangkal Penyebaran Corona di Kampus. Vivanews 2020. https://www.vivanews.com/berita/nasional/39480-begini-langkah-uitangkal-penyebaran-corona-di-kampus?medium=autonext (accessed March 17, 2020). https://doi.org/10.15408/sjsbs.v7i3.15103

[12] Lim I. Covid-19: Universiti Sains Malaysia to go into lockdown for three weeks at all campuses. MalaymailCom 2020. https://www.malaymail.com/news/malaysia /2020/03/16/covid-19-universiti-sains-malaysia-to-go-into-lockdown-for-three-weeks-ata/1847113 (accessed March 16, 2020). https://doi.org/10.21315/jps2020.31.1.8

[13] BW Online Bureau. COVID 19: Battling University Lockdown Through MOOCs Courses and Online Education. BusinessworldIn 2020. http://www.businessworld.in/article/ COVID-19-Battling-University-Lockdown-Through-MOOCs-Courses-And-OnlineEducation/16-03-2020-186277/ (accessed March 16, 2020). https://doi.org/10.7176/jep/1120-11

[14] Nurhadi M. COVID-19 Menyebar, Berikut Daftar Kampus di Yogyakarta Melakukan Lockdown. SuarajogjaCom 2020. https://jogja.suara.com/read/2020/03/14/174000/covid19-menyebar-berikut-daftar-kampus-di-yogyakarta-melakukan-lockdown (accessed March $16,2020)$.

[15] Ramdhani MA, Wulan ER. The Analysis of Determinant Factors in Software Design For Computer Assisted Instruction. Int J Sci Technol Res 2012.

[16] Raman K, Othman N, Danaraj G. Investigating key factors for successful e-learning implementation. Asia Proc Soc Sci 2019; 4: 49-52. https://doi.org/10.31580/apss.v4i2.725

[17] Umana MK. Determinant factors in multimedia-based e-learning design. IOP Conf Ser Mater Sci Eng 2018; 434 :012282. https://doi.org/10.1088/1757-899X/434/1/012282.

[18] Aulawi H, Amin AS. E-learning analysis and design based on technology acceptance model. Int J Sci Technol Res 2019.

[19] Gerhana YA, Irfan M, Slamet C. Implementasi Technology Acceptance Model untuk Mengukur Penerimaan Guru Terhadap Inovasi Pembelajaran (Studi Kasus Model Pembelajaran CBR Di SMK) 2017; X:1-18.

[20] Scherer R, Siddiq F, Tondeur J. The technology acceptance model (TAM): A metaanalytic structural equation modeling approach to explaining teachers' adoption of digital technology in education. Comput Educ 2019; 128:13-35. https://doi.org/10.1016 /j.compedu.2018.09.009

[21] Dumpit DZ, Fernandez CJ. Analysis of the use of social media in Higher Education Institutions (HEIs) using the Technology Acceptance Model. Int J Educ Technol High Educ 2017;14:5. https://doi.org/10.1186/s41239-017-0045-2

[22] Wingo NP, Ivankova N V, Moss JA. Faculty perceptions about teaching online: Exploring the literature using the technology acceptance model as an organizing framework. Online Learn 2017; 21:15-35. https://doi.org/10.24059/olj.v21i1.761

[23] Chang C-T, Hajiyev J, Su C-R. Examining the students' behavioral intention to use elearning in Azerbaijan? The general extended technology acceptance model for e-learning 
approach. Comput Educ 2017; 111:128-43. https://doi.org/10.1016/ j.compedu.2017.04.010

[24] Tarhini A, Elyas T, Akour MA, Al-Salti Z. Technology, demographic characteristics and e-learning acceptance: a conceptual model based on extended technology acceptance model. High Educ Stud 2016; 6:72-89. https://doi.org/10.5539/hes.v6n3p72

[25] Al-Azawei A, Parslow P, Lundqvist K. Investigating the effect of learning styles in a blended e-learning system: An extension of the technology acceptance model (TAM). Australas J Educ Technol 2017;33. https://doi.org/10.14742/ajet.2741

[26] Naveed QN, Qureshi MRNM, Shaikh A, Alsayed AO, Sanober S, Mohiuddin K. Evaluating and ranking cloud-based e-learning critical success factors (CSFs) using combinatorial approach. IEEE Access 2019; 7:157145-57. https://doi.org/10.1109/access.2019.2949044

[27] Burkardt AD, Krause N, Velarde MCR. Critical success factors for the implementation and adoption of e-learning for junior health care workers in Dadaab refugee camp Kenya. Hum Resour Health 2019;17:98. https://doi.org/10.1186/s12960-019-0435-8

[28] Al-Jedaiah MNS. Knowledge Management and E-Learning Effectiveness: Empirical Evidence from Jordanian Higher Education Institutions. Int J Emerg Technol Learn 2020; 15:50-62. https://doi.org/10.3991/ijet.v15i05.11653

[29] Wahyudi W. The Effectiveness of Sharing Blended Project Based Learning (SBPBL) Model Implementation in Operating System Course. Int J Emerg Technol Learn 2020; 15:202-11. https://doi.org/10.3991/ijet.v15i05.11266

[30] Ratnawati N, Idris I. Improving Student Capabilities through Research-Based Learning Innovation on E-Learning System. Int J Emerg Technol Learn 2020; 15:195-205. https://doi. org/10.3991/ijet.v15i04.11820

[31] Al-Fraihat D, Joy M, Sinclair J. Evaluating E-learning systems success: An empirical study. Comput Human Behav 2020; 102:67-86. https://doi.org/10.1016/j.chb.2019.08.004

[32] Lestari AS, Hamka SR. Analisis PIECES dalam Implementasi Kebijakan E-Learning di IAIN Kendari. Manag J Manaj Pendidik Islam 2019; 4:103-25. https://doi.org/10.14421/ma nageria.2019.41-07

[33] Wulandari IR, Farida LD. Pengukuran user experience pada e-learning di lingkungan universitas menggunakan User Experience Questionnare (UEQ). J Mantik Penusa 2018; 2:146-51.

[34] Agustina R, Santosa PI, Ferdiana R. Sejarah, tantangan, dan faktor keberhasilan dalam pengembangan e-learning. Semin Nas Sist Inf Indones 2016 2016:209-17.

[35] Saaty TL. Decision making for leaders: the analytic hierarchy process for decisions in a complex world. Pitsburg: RWS publications; 1990.

[36] Saaty TL, Vargas LG. Decision making in economic, political, social, and technological environments with the analytic hierarchy process. vol. 7. Pitsburg: RWS publications; 1994.

[37] Saaty TL. Fundamentals of decision making and priority theory with the analytic hierarchy process. vol. 6. Pitsburg: RWS publications; 2000.

[38] Adila FA, Chamsudin A. Efektifitas e-Learning dan collaborative learning untuk meningkatkan communication skill pada mata pelajaran komputer dan jaringan dasar. Surakarta: 2019. https://doi.org/10.29165/komtekinfo.v5i3.193

[39] Sakdiyah L, Effendi R, Kustono AS. Analisis Penerimaan Penggunaan E-Learning dengan Pendekatan Theory of Planned Behavior (TPB) pada Mahasiswa Akuntansi Universitas Jember. E-Journal Ekon Bisnis Dan Akunt 2019; 6:120-6. https://doi.org/10.19184/ejeba. v6i2.11151 
[40] Warni M. Pengaruh Komitmen Organisasi dan Pengetahuan Manajer terhadap Keberhasilan Penerapan Sistem Informasi Akubtansi Pada Bank BRI Pasir Pengaraian. J Mhs Prodi Akunt Fak Ekon 2019;1.

[41] Sutrisno E. Budaya organisasi. Prenada Media; 2019.

[42] Riyani U, Syaifullah S, Ahsyar TK, Megawati M, Jazman M. Pengaruh budaya organisasi terhadap efektivitas penerapan e-learning dengan metode OCAI dan Hot Fit. J Ilm Rekayasa Dan Manaj Sist Inf 2019; 5:161-70.

[43] Meylasari US, Qamari IN. Faktor-faktor yang kempengaruhi knowledge sharing dalam implementasi e-learning. J Manaj Bisnis 2017; 8:238-63.

[44] Haryanto B. Strategi Perguruan Tinggi Swasta Berbasis Agama Membangun Budaya Organisasi untuk Meraih Keunggulan Kompetitif. Halaqa Islam Educ J 2019; 3:67-73. https:// doi.org/10.21070/halaqa.v3i1.2119

[45] Iskandar J. Kapita Selekta teori Administrasi Negara. Bandung: Puspaga; 2016.

[46] Jayady A. Teknologi Konstruksi: Sebuah Analisis. J Karkasa 2018; 4:13-20. https://doi. org/10.32531/jkar.v4i1.92.

[47] Dewi NKSC, Suyanta IW. Pembelajaran seni dan teknologi digital sebagai media belajar dan perkembangan anak usia dini. Pratama Widya J Pendidik Anak Usia Dini 2019; 3:112-9. https://doi.org/10.25078/pw.v3i1.710

[48] Divayana DGH. Evaluasi pemanfaatan e-learning menggunakan model CSE-UCLA. Cakrawala Pendidik 2017; 36:280-9. https://doi.org/10.21831/cp.v36i2.12853

[49] Khumaidi A, Riantini R, Munir M, Atmoko RA. Pengembangan Network and Services Monitoring System untuk Meningkatkan Keandalan Sistem Informasi Perguruan Tinggi. Semin. MASTER PPNS, vol. 2, 2017, p. 39-44.

[50] Ningrum MVR, Rosita D. Pengembangan e-learning berbasis Moodle di Fakultas Keguruan dan Ilmu Pendidikan Universitas Mulawarman. Sebatik 2019; 23:517-21. https://doi. org/10.46984/sebatik.v23i2.808

[51] Tambun S, Muhtiar I. Pengaruh pengetahuan perpajakan dan penerapan e-system terhadap kepatuhan wajib pajak yang di moderasi oleh technology acceptance model. MEDIA Akunt Perpajak 2019; 4:1-15. https://doi.org/10.35314/inovbiz.v7i1.979

[52] Davis FD. Perceived Usefulness, Perceived Ease of Use, and User Acceptance of Information Technology. MIS Q 1989. https://doi.org/10.2307/249008.

[53] Mazaya MS. Logical framework for smart discussion in learning process. J Phys Conf Ser 2019; 1157:42002. https://doi.org/10.1088/1742-6596/1157/4/042002.

[54] Darliah L. Pengaruh kualitas informasi dan penggunaan e-learning terhadap prestasi belajar dengan motivasi belajar sebagai variabel intervening. Yogyakarta: 2016. https://doi.org/ 10.17509/jpm.v1i1.3344

[55] Mazaya MS. Effective practical learning model for the subject of basic information technology. J Phys Conf Ser 2019; 1157:42003. https://doi.org/10.1088/1742-6596/1157/4/042 $\underline{003}$.

[56] Davenport TH, Prusak L. Working knowledge: How organizations manage what they know. Boston: Harvard Business Press; 1998. https://doi.org/10.1108/nlw.2000.101.6.282. $\underline{4}$

[57] Irma Becerra-Fernandez RS. Organizational knowledge management: A contingency perspective. J Manag Inf Syst 2001; 18:23-55.

[58] Ilham M, Hayon PP. Pengaruh komitmen organisasi dan pengetahuan manajer terhadap keberhasilan penerapan sistem informasi akuntansi (Studi kasus pada kantor distrik dan kampung-kampung di Distrik Semangga Kabupaten Merauke). J Ilmu Ekon Sos 2018; 9:62-73. https://doi.org/10.35724/mustek.v7i1.1496 
[59] Putra DS, Atmadja AT, Darmawan NAS. Pengaruh Pengetahuan Karyawan Bagian Akuntansi dan Pemanfaatan Teknologi Informasi Terhadap Efektivitas Sistem Informasi Akuntansi (Studi Empiris Pada Hotel yang Terletak di Kawasan Lovina, Kabupaten Buleleng). JIMAT (Jurnal Ilm Mhs Akuntansi) Undiksha 2014; 2:1-6. https://doi.org/10.24843/eja.2018.v23.i01.p14

[60] Nugroho AA, Astuti DSP, Kristianto D. Pengaruh Teknologi Informasi, Kemampuan Teknik Pemakai, Dukungan Manajemen Puncak Dan Kompleksitas Tugas Terhadap Kinerja Sistem Informasi Akuntansi. J Akunt Dan Sist Teknol Inf 2019; 14:507-18. https://doi.org/10.31937/akuntansi.v9i1.588

[61] Notoatmodjo S. Promosi Kesehatan dan Ilmu Perilaku. Jakarta: Rineka Cipta; 2007.

\section{Authors}

Tedi Priatna is a professor at the Department of Islamic Education at the UIN Sunan Gunung Djati Bandung, Indonesia. His current research interests focus on Islamic Education. ORCID ID: 0000-0002-8491-5405

Dian Sa'adillah Maylawati is a lecturer in the Department of Informatics at the UIN Sunan Gunung Djati Bandung, Indonesia. Her current research interests focus on Software Engineering, Expert System, Text Mining, and Natural Language Processing. She takes the Ph.D degree of Information and Communication Technology in Universiti Teknikal Malaysia Melaka (UTeM). ORCID ID: 0000-0002-1193-3370

Hamdan Sugilar is a lecturer in the Department of Mathematics Education at the UIN Sunan Gunung Djati Bandung, Indonesia. His current research interests focus on Mathematics Education. ORCID ID: 0000-0001-8588-3372

Muhammad Ali Ramdhani is a professor in Research of Information Technology in the Department of Informatics at the UIN Sunan Gunung Djati Bandung, Indonesia. His current research interests focus on Information System, Expert System, Decision Support System, Strategic Management, and Research Methodology. ORCID ID: 0000-0002-6492-067X

Article submitted 2020-03-18. Resubmitted 2020-05-22. Final acceptance 2020-05-22. Final version published as submitted by the authors. 